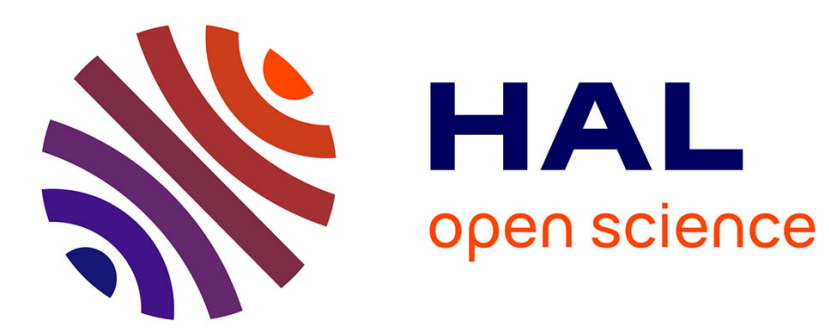

\title{
Troubling complicity: audience ethnography, male porn viewers and feminist critique
}

Florian Vörös

\section{To cite this version:}

Florian Vörös. Troubling complicity: audience ethnography, male porn viewers and feminist critique.

Porn Studies, 2015, 10.1080/23268743.2015.1052936 . halshs-01484110

HAL Id: halshs-01484110

https://shs.hal.science/halshs-01484110

Submitted on 6 Mar 2017

HAL is a multi-disciplinary open access archive for the deposit and dissemination of scientific research documents, whether they are published or not. The documents may come from teaching and research institutions in France or abroad, or from public or private research centers.
L'archive ouverte pluridisciplinaire HAL, est destinée au dépôt et à la diffusion de documents scientifiques de niveau recherche, publiés ou non, émanant des établissements d'enseignement et de recherche français ou étrangers, des laboratoires publics ou privés. 
Florian Vörös, « Troubling complicity: audience ethnography, male porn viewers and feminist critique », Porn Studies, vol. 2, n 2-3, 2015, p. 137-149.

Keywords: Pornography, audiences, methodology, feminist, masculinities

Abstract: This article offers a self-reflexive account of an audience reception study conducted in Paris, France, examining gay, bisexual and heterosexual cisgender men's everyday (and everynight) uses of pornography. The study explores the gender dynamics at work in practices such as surfing, watching, reimagining and discussing pornography, based on indepth interviews with 34 viewers, combined with the replication of their online sexual meanderings; this positions me as a viewer among others, with specific epistemic goals. The article analyzes porn audiences' accounts of pornographic tastes, fantasies and attractions, both in relation to the interviews' interactional setting and to normative public representations of the "responsible" viewer. As a verb, troubling refers to a strategy: I grasp viewers' multifaceted relations to pornography through the strategic use of complicit empathy and feminist contradicting. As an adjective, troubling refers to an aporia: while this study is oriented towards feminist goals, it implies my participation as an ethnographer in hegemonic complicity, the process by which female and feminist views are demeaned in homosocial male bonding. 
"Ethnography requires its share of bodies" (Elspeth Probyn, 1989: 20)

\section{Introduction}

This article offers a self-reflexive account of ethnographic fieldwork conducted in Paris, France on the everyday-and-everynight-life uses of pornography and the production of masculinities. ${ }^{1}$ This study aimed to explore the gender dynamics at work in gay, bisexual and heterosexual cisgender men's use of online pornography. It examines the cultural practices of browsing and clicking, watching and listening, panting and stroking, saving and archiving, sharing and expressing, reimagining and reflecting upon.

Fieldwork consisted of audio-recorded interviews, privileging thoroughness (interviews lasted from 1 to 6 hours, some repeated) over quantity. ${ }^{2}$ During interviews, participants were offered opportunities to comment on their favorite online pornography from a laptop. Alongside, I replicated each interviewee's typical online sexual meandering by navigating the pornographic blogs, tubes, tags and videos mentioned during interviews. The notion of "meandering" stresses the pleasurable, processual and nonlinear aspects of navigating porn. Reliving my interviewees' browsing and viewing practices expanded my knowledge of the diversity of online pornographies; more importantly, it refocused my attention to the technical and bodily materiality of online pornography (Paasonen 2011) and domestic autosexuality. Avoiding the genital connotations of "masturbation," autosexuality refers to a wider range of bodily practices (to "feel”, "pant", "stroke”, “work", “plug”, etc.) oriented towards sexual intensification. It also highlights the everyday-and-everynight-life selfreflexivity at work in pornographic routines: "a form of self-interaction with one's own body and imagination, mediated through particular forms of cultural expressions, representations and performances" (Attwood 2002: 100).

This approach can be described as interpretative in the Weberian sense that it relies on the subjective meaning viewers assign to their own practices. Following Cultural Studies traditions of audience ethnography (Morley and Brunsdon 1999; Radway 1991), all media reception practices, even those framed and experienced as purely physical (Dyer 1985,

\footnotetext{
${ }^{1}$ Fieldwork began in 2008 when undertaking a Masters degree on the receptions of gay male pornography. It ${ }^{2}$ Participants gave oral consent to being interviewed after a short presentation of my research and a guarantee of anonymity.
} 
Williams 1991), are understood as involving active production of meaning by audiences ${ }^{3}$. In the reconstitution of participants' online pornographic meanderings I drew on my own "somatic archives", the "historically layered skills, experiences and sensations that bring forth particular ways of relating to other bodies and reverberating with them" (Paasonen 2011: 202). This strategic use of the body has roots in feminist and queer ethnography (Probyn 1989, 1993; Kulick and Wilson 1995; Lewin and Leap 1996). It also echoes audience studies' renewed interest in viewers' affective reactions (Skeggs and Wood 2012). This two-step methodology establishes a double mediation of porn viewers' experiences: what pornography means and does to the men who participate in this study is reconstructed by the interactional setting of our encounter and translated through my own somatic archives. Acknowledging the energy I deployed in interviews enables reflection on ethnographic complicity, from the specific vantage point of an early-career queer scholar, raised and perceived as male, white and middle-class, mostly interacting in my fieldwork with white middle-class gay, bisexual and heterosexual male viewers. In what follows, I explore the tensions between pornographic pleasure and academic scientism and then reflect on the tensions between male complicity and feminist critique, as I move progressively from an empathic to a critical tone during face-to-face interviews.

\section{Talking about porn}

Qualitative research is interested in the diversification of comparable cases rather than in the construction of representative samples. This study sought to explore the diversity of peoples' investments in porn cultures, in order to compare porn enthusiasts with discrete or reluctant consumers ${ }^{4}$. I used three parallel recruitment strategies and disseminated three different ads in order to reach a broad range of men with experiences of pornography. In ad A, posted on two online forums for (mostly heterosexual male) porn fans and on two gay dating websites (where studio and home-produced pornography circulate), I presented myself as a $\mathrm{PhD}$ student looking to recruit "porn spectators (fans, enthusiasts or occasional consumers)". The two other ads mentioned pornography within a larger list of audiovisual representations of sexuality ("cinema, sitcoms, documentaries, porn, erotica, etc.") in order to attract

\footnotetext{
${ }^{3}$ This argument has successfully been made by previous studies of porn audiences (Hardy 1998; Attwood 2005; Smith 2007; McKee, Albury and Lumby 2008; Mowlabocus, Harbottle and Witzel 2013, Smith, Barker and Attwood, 2015).

${ }^{4}$ In the Contexte de la Sexualite en France quantitative survey, conducted in 2006 upon a randomized sample of 12.000 people representative of the population living in France, one woman out of five and one man out of two declare as regular viewers (Bozon 2012). No major discrepancies can be observed among men of different social classes.
} 
respondents who might not have been interested in being interviewed exclusively about pornography ${ }^{5}$. Ad B was oriented towards gay men and mentioned "representations of male homosexuality on screen". Ad C was oriented towards heterosexual men and made more general mention of "love and sexuality on screen". Ads B and C were circulated via snowballing methods, passed on from a first interviewee, who then pointed me towards another friend of theirs, and so on.

These three recruitment strategies garnered 34 interviewees, 14 of whom define as gay men, 13 as heterosexual men, three as bisexual men, two as lesbians, on as a bisexual woman and one as a pansexual transmasculine person. ${ }^{6}$ Interviewees' ages ranged from 24 to 62 (average: just under 40). Spreading my ad through geolocalized gay dating devices and friendship networks led to an overrepresentation of middle and upper class white men. Most identified as White, two as Black/mixed-race and one as Asian. Half work as managers and professionals, though only one tenth of the total French population have such positions. This over-representation still presents the opportunity to examine the reconfigurations of hegemonic masculinity (Connell and Messerschmidt 2005) at work in the reception of gay and straight pornographies.

Pornographic tastes and fantasies are usually not shared at any time, any where or with any body. Indeed, a comparative analysis of the interviews indicates three models of pornographic sociability. A first group - mostly heterosexual men whose spouses understand pornography as degrading and whose male friends consider interest in the genre immature never, or only rarely, talk about their pornographic practices. A second group - mostly gay men, for whom online dating, saunas and sex clubs are important forms of sexual intimacy talk about pornography with their sexual partners only. A third group - heterosexual men on online porn fan forums, or gay men intensely socialized within "the scene" and who consider pornography an important part of gay culture - frequently talk about pornography within particular social circles. No matter how enthusiastic about, or socialized through, pornography respondents were, their pornographic worlds - simultaneously male homosocial worlds $^{7}$ - tend to be kept separate from other social worlds (Schütz 1945) they engage in. The

\footnotetext{
${ }^{5}$ During the interviews, most viewers recruited through ads B and C insist they are not porn "consumers", "fans" or "addicts".

${ }^{6}$ The interviews with women and trans viewers enable comparisons of cisgender, cross-gender and transgender dynamics of masculine embodiment in the receptions of pornography but are not discussed here.

${ }^{7}$ On pornography and male homosociality, see (Waugh 2004, Shelton 2013).
} 
ethnographic relation is therefore a theater for the reenactment of the affective qualities, and material and discursive frontiers of these homosocial worlds.

Most interviews took place at the interviewee's home or mine, in private and isolated from other social times and spaces. Fabrice (42, sound technician, heterosexual man, married with children) was interviewed in his living room, in the afternoon when his wife was at work and his three children at school. We sat on the couch where he watches porn DVDs mostly at night when the family is asleep. Such interviews replicated the domestic spatiality and temporality of porn reception practices. When I met Michel (43, executive officer, bisexual man, single) at the suburban train station near his house, he was, at first, uncomfortable. Only when we got to his home and he had changed his work suit for some casual sportswear, were the words "gay", "bisexual" and "pornography" first spoken. Such conversation only became possible after mutation from the public persona (the manager returning from work) to the private persona (the "gay porn maniac" as he described himself). Only after a first interview in my living room did Jean-Claude (52, bailiff, gay man, non cohabitant couple) open the door of his own flat and show me how he connects his computer to a flat TV screen and navigates his favorite barebacking blogs.

\section{Sharing intimacy}

The tensest stage in the interview came with the revelation of pornographic attractions. Sharing pornographic tastes requires using "dirty" language and evoking sexual sensations and masturbation, which, from bourgeois standards, equate with "vulgarity" (Elias 2000). Marc (47, engineer, White, bisexual man) answered the question "What makes good porn?" by listing the pornographic subgenres and styles he disliked. After distancing himself from those, he finally said, in a low voice that he can be turned on by "those banlieue babes". In the French imaginary, "la banlieue" refers to the "dangerous" poor and non-White suburbs of post-industrial cities. Marc implicitly referred to Citébeur, since the early 2000s the leading French gay porn studio, which mainly eroticizes "lascar [thug]" masculinity. After sharing this preference, he immediately clarified:

It bothers me to admit I like it, because I'm not into violence, domination or vulgarity. Yet this is precisely what is conveyed by these videos. It's annoying to be in such contradiction with myself.

Echoing Marc's discomfort with the racial stereotyping at work in these "banlieue babes" pornographic fantasies, Adrien (29, artist, heterosexual man) was embarrassed that he was 
aroused by representations of female submissiveness. The gap between the highbrow cinematographic representations of sexuality he values and the commercial porn videos he actually watches daily prevented us talking about the latter during the first hour of our interview. Just as Marc insisted he does not feel "represented" by "violent and vulgar" fantasies he framed as "not significant", Adrien insisted he was not a "beauf $f^{8 "}$. Within a Western sexual epistemology that conceives fantasies as confessions of identity (Foucault 1978), the act of sharing one's "own" fantasies can be perceived as a dangerous disclosure that may lead to "losing face" (Goffman 1959).

On one of the two hetero porn fan forums, my call for respondents generated a stormy conversation thread. Some forum members asked me to prove I was an authentic (straight) porn fan. I didn't respond to these demands because they were expressed in a heteronormative language I did not want to confront while attempting to recruit participants. Other forum members asked me to prove my scientific status and motivations. I responded with a link to my academic webpage, which authenticates my $\mathrm{PhD}$ student status ${ }^{9}$. A month later, a national television journalist appealed to the same forum seeking "personal accounts of people who devote an enormous amount of time to pornography" - respondents could keep their faces covered if they wished to remain anonymous. Reactions on the forum were unanimously negative ranging from protestation to insult and parody. In displaying the typical medical gaze over "excessive" consumers - delineating them as suffering and shameful - this journalist indirectly put a new value on the interpretative sociological approach I had been defending on the forum.

In the middle-class homosocial male context of these interviews, the status of "sociologist" and/or "participant in a scientific investigation" gave a legitimate frame to my interviewees, establishing the idea of having a conversation "between educated men", even so, pornographic words and images may provoke a temporary destabilization of that legitimizing frame. Some interviewees attempted to euphemize the intensity of bodily sensations involved in the act of watching porn by emphasizing their reflexive distance to the conventions that organize pornography as a cinematic genre. During our two interviews Gérard (62,

\footnotetext{
${ }^{8}$ Derogatory term alluding to a typically French poorly educated chauvinist male.

${ }^{9}$ This incident acts as a reminder that researching pornography is still often perceived, both inside and outside academia, as a dubious activity (Burke 2014, Marks 2014).
} 
heterosexual, divorced, retired, porn forum member) constantly evaded questions about attractions and sensations:

- Which words do you use when you're browsing on a porn tube?

- [Hesitates] Stuff such as gangbang or bukkake [ill-at-ease]... Well I suppose you know the vocabulary. All this is completely out of touch with reality.

- And you enjoy watching gangbangs, bukkakes, that kind of stuff?

- Well [ill-at-ease]... Yes, I enjoy it [long silence]... Nowadays porn is full of niches and specialties. It's a genre which could very rapidly become monotonous. Just as antiporn campaigners say: it's always the same thing. But I think it is true for any genre: look at detective novels, they always end the same way too.

Gérard answered reluctantly and insisted on the aesthetic and critical distance he maintains to "gangbang" and "bukkake" imagery. While an intellectual conversation on pornography, as a filmic genre or as a social problem, positions Gérard as an active subject within the "pornography debate", this upper-middle-class male felt a more embodied conversation on personal pleasures, fascinations and attractions, risked making him a passive object of public concern. The way audiences account for their pornographic fantasies in specific interactional settings cannot be separated from the available representations of the "good" viewer ("responsible", “educated", "reflexive", "distant", “adult", "mature"), shaped in public debates over pornography and its effects ${ }^{10}$.

Gérard's reluctance to talk reflects the disembodied scientific gaze from which pornography is traditionally studied. The will to knowledge about pornography's "effects" emerges in Western Europe in the early $19^{\text {th }}$ century with attempts at censorship of the "obscene". Kendrick (1987: 15) traces its foundational epistemic mode in an 1867 art history book presenting "pornographic" objects excavated from the ruins of Pompeii. In the book's introduction the author, Louis Barré, insists on two conditions for publication: first, that women and children should not access it; second, that "men of science" should read it "without blushing". Contemporary study of pornography inherits from this founding gesture the set of tired yet stubborn binaries,"us and them", "reason and emotion", "mind and body", "objectivity and subjectivity", which produce the image of a passive audience and of an untouched researcher (Attwood 2007). While sexuality remains a reassuring scientific object when it is embodied by "others", it becomes a challenge to conventional social science rationality once it is embodied by the researchers themselves (Kulick and Wilson 1995,

\footnotetext{
${ }^{10}$ Clarissa Smith, Martin Barker and Feona Attwood (forthcoming) subtly analyze how teenagers' answers to their questionnaire are in part written in reaction to adult discourse over the "risks" and "dangers" of pornography.
} 
Irvine 2014): scientific comfort is traditionally produced by the neat distinction between embodied objects and disembodied subjects.

Shame intensifies as it circulates among bodies (Ahmed 2004: 9) and ethnographers may trigger or reinforce it. Interviewees may also use a wide range of tactics to prevent embarrassment. Irony over the hyperbolically masculine and feminine performances of gender in commercial pornography is one of the ways by which queer interviewees overcome the unease associated with the use of vulgar and objectifying language. Tom (29, no stable profession), a butch lesbian who enjoys watching emphatically masculine gay male porn, uses such camp humor to reveal her normative tastes:

- To you, what's a bad porn video?

- Can I get dirty?

- Go for it!

- [Ironically masculine tone] OK so it's the video of a dude being fucked by another dude who either doesn't have a hard-on or has a small dick [laughs].

Cultures of porn fandom and online cruising have also invented alternative ways of dealing with the carnality of pornographic fantasies. Porn enthusiasts draw parallels between participating in sociological research and participating in online conversations with other fans and skillfully translate into words the bodily experience of navigating, watching and feeling the sounds and images. Writing sexual fantasies to potential sexual partners through online messaging services enabled some gay men's easy expression of their pornographic fantasies during interviews. In his first message to me on GayRomeo.com, Bruno (53, gay, executive officer), adopted a very straightforward tone:

I would be very happy to meet you, as I classify as a casual gay porn consumers: that is, a few video clips every now and then from blogs such as Trouajus.com [literally: "cumhole.com"] and porn movies that some of my fuckbuddies play when we fuck at their place.

As I set my audio recorder for our interview, Sébastien (37, gay, secondary school teacher) humorously referenced the erotics of recording pornographic fantasies and compared it to his habit of audio recording his own sexual acts. At the end of the interview, he asked if I "hookup a lot", mischievously comparing sociological recruitment to sexual cruising. Laurent (42, gay, executive officer) told me of his roommate's suspicions that my research might be a creepy pretext for having sex. Sharing pornographic fantasies is indeed often associated with the hopes and fears of merging and mingling bodies. Bruno (53, gay, executive officer) never discusses pornography with his gay male colleagues because "if we start talking of porn and 
this kind of stuff, the risk that we lose control becomes really high". Pornographic words are given the power to break social norms of modesty and to lead to "wild" sexual drives (Gagnon and Simon 2004: 197-202). While Bruno believes "talking about porn is almost like having sex", he added an exception: "but with you it's different because you have a scientific, sociological approach”.

Various phases of the interview with Frédéric (28, gay man, architect) illustrate the sexual dynamics at work in the ethnographic relation with gay and bisexual men. In our first message exchanges on a cruising website, Frédéric worried he might get an erection during the interview. I reassured him by answering that "it's part of my work" and erections were nothing to be worried about. I used "work" to normalize interactions which interviewees labeled awkward and uncomfortable. One hour into our interview, when we were about to navigate his favorite porn blogs together, Frédéric's anxiety resurfaced: “It's gonna feel weird to watch porn in front of you". He however started browsing and clicking after I reassured him that I was used to this situation because it was work. Concentrating on finding and showing the videos that turn him on ("amateur" videos of "straight" college boys masturbating each other), Frédéric was surprised he wasn't turned on by the situation: the interactional context of the interview neutralized the carnal appeal of pornographic sounds and images. For my part, when we continued the interview by phone a few days later I found myself disturbingly turned on by his - perhaps intentionally - arousing descriptions of gestures and moves in porn.

The second phase of the research process, transcribing interviewees' accounts, brought in another, technologically mediated, way of sharing intimacy with participants. One form of affective labor replaced another: during interviews, I reassured, listened and prompted; after the interview, I work at capturing the intensity of their responses. Transcribing interviews meant inhabiting other viewers' fantasies and being moved in unexpected ways. Interviewees' words resonate with the transcriber's "fleshy memories" and "somatic archives" (Paasonen 2011: 202-204) and key hypotheses emerge from these intersubjective connections.

Simultaneously, I replicated each interviewee's typical online sexual meandering by navigating the pornographic websites, tags and videos mentioned during the interviews. I slipped myself into their pornographic fantasies, comparing what I saw and felt with 
interviewees' descriptions. From my own experiences, I tried to access how a gesture, glance or moaning might feel to a viewer's body with a different history to mine. Through my own domestic viewing experience I open up the affective intensity of autosexual pornographic routines usually bound to domestic privacy. Thus, in each step of the research process meeting, chatting, reassuring, browsing, feeling and interpreting - I participate, as an ethnographer, in the gender dynamics I seek to reveal.

\section{Hegemonic complicity}

Working from the concepts of "male homosocial desire" (Sedgwick 1985) and hegemonic masculinity (Connell and Messerschmidt 2005), I refer to "hegemonic complicity" as the process by which female and/or feminist views are demeaned in homosocial male bonding. In the affective sense of "connivance", complicity may refer to the bodily and discursive performances of masculinity that allow the circulation of positive affects (feeling "at ease" and "at home") that allow interviewees to kick back and talk freely. Pornographic homosocial pleasures may then contrast with "bad spirit" and "killjoy" feminism (Ahmed 2010). In the more straightforward political sense of "collusion", hegemonic complicity refers to the mechanisms by which female and/or feminist standpoints are disregarded in male homosocial settings.

Both within online spaces where I publicized my research and during face-to-face interviews, I presented as a researcher and a viewer-among-others - and more specifically as a "porn enthusiast" on online hetero porn fan forums and online gay dating websites. On fan forums, I chose an "I love porn" magnet as an avatar. I also followed the sexualized self-presentation encouraged by online gay dating websites giving details of my sexuality, age, build, ethnicity, body modifications etc. I did not, however, give details of my sexual "preferences" or "fetishes". My profile made clear my intention to converse with porn consumers as part of a sociological investigation. Participant self-censorship can be widespread in the study of "illegitimate" cultural practices, presenting as a peer can avoid this, as can starting conversations with a shallow question: "Do you remember the first time you watched porn?" (with participants recruited as porn viewers) or "What is the first sexual image on screen you remember?" (with participants recruited as "love and sexuality on screen" viewers). Then, progressively, we delve into the more intimate and controversial aspects of the practice of watching porn. 
During the interviews, I adopted a resolutely empathic posture at first - performing attention and openness by smiling and nodding, especially when "intimate" or "dirty" words were used, in order to avoid the self-censorship that might result from the perception of me as representing elite culture and moral standards. I also drew on shared identifications and subcultural affinities in order to create complicity, whether queerness, porn fandom or, more broadly, being part of the same audience and sharing common cultural references. For instance, when I explained my research to Julien (28, manager, heterosexual single, online fan forum member) at the beginning of our interview, I skipped over my feminist focus on masculinities, thinking it probably better not to start with that given what I read as a conventional performance of masculinity when he greeted me with a handshake. I explained that I was interviewing porn enthusiasts and viewers who cannot imagine porn cinephilia exists, Julien responded: "People who don't want to imagine it exists!" We smiled in agreement. He asked me how colleagues view my research, to which I responded "the usual, most academics prefer to remain closeted porn viewers", echoing his concerns that his professional career may be jeopardized by his passion for pornography. This preliminary conversation enabled a relation of confidence, from which we easily slipped into the interview.

Porn conversations between men contribute to a masculinized sense of sexual liberation. Asked to retrace his career as a sexual media consumer, Adrien (29, heterosexual, artist) insisted he is "free", liberated from sexual conventions and constantly "struggle[s] at being [him]self". Sexuality in general, and pornography in particular, are fertile ground for the display of the - historically, bourgeois - narrative of the individual struggling against society. Transgressing standards of modesty is another way to produce such "liberation". Historically, sexual humor within male homosocial settings is, in France, marked as working-class. Pornography also tends to be associated with the "lower classes" (Kipnis 1998: 175). This contexts helps make sense of how Gérard (62, heterosexual, retired police inspector) recalls conversations with colleagues of lower professional status at the police station where he once worked:

Back in the 70s, everybody was going to the porn theaters, but nobody would publicly admit it [he laughs]. It wasn't easy to admit. And it still isn't. Although it's easier now. [...] You know, cop conversations often aren't really high level. I remember a colleague asking during lunch "So, who goes to the porn movies?" This colleague was in his fifties, not far from retirement. I really remember his smiling face when he exclaimed "Well $I$ go there... and [louder voice] it gets me hard!" [we both laugh] 
In both settings - the police station and the sociological interview - the public admission of the speaker's erection invites a male audience to collectively transgress the standards of bourgeois modesty (keeping the genitals private) through laughter. In our interview, as "educated men" talking about "regular cops", such pornographic laughter has specific effect: by mimicking "vulgar" working-class humor, "educated men” are temporarily liberated from their own embodied cultural standards of "good taste" and "sexual reserve".

Heterosexually-identified men often describe informal conversations with male friends about pornography as a moment of "evasion" and "freedom", both from their job and their spouses. The only times Vincent (30, married heterosexual man, manager) talks of pornography is with friends he has known since adolescence and with whom he learned to "hit on women". Now all married, they go on weekend holidays together a couple of times per year and pornography is one of the topics through which they bond. Pierre (44, cook, single heterosexual, fan forum member) speaks ironically of his married friends hypocritical relation to pornography:

My neighbor often passes an hour or so at my place during the evening. We smoke a joint. I show him the latest porn I've received. He's married, with children. He often says "Wow! Fantastic! I want this video!" So I say "Sure: what format do you want?" Then he gets confused, not so much thinking about where he's gonna put the video because he knows I can lend him a USB drive - but thinking about how he's not gonna get caught [laughs]!

Louis (30, engineer, single, heterosexual) makes clear distinctions about conversations on porn with men and with women. He frames the latter as "naturally" part of seduction, hopefully leading to hetero sex:

I prefer to talk about porn with chicks than with dudes. It turns me on so much. There's a sexy side to it. Chicks are so complicated that, when they are cool enough to accept the topic, it's usually because... Well I take this as a "Let's go!" sign. You know, getting closer and so on. [...] From the moment we're watching porn together it becomes crazy. I mean if one of us proposes we watch porn together, let's stop pretending, everybody knows what's gonna happen!

Louis compares these "cool women" to the "complicated women" who interrogate the gender power relations at work in his pornographic fantasies. Commenting on his mixed feelings towards a gangbang porn scene he watched the week before, Louis positions "feminists" in a necessarily antagonistic relation to his pornographic fantasies: 
You show this to a feminist, either she slashes her wrists or she slashes the wrists of the dude that's next to her, or she throws him through the window!

Discussing heterosexual pornography means discussing a genre subject to intense feminist debate over the past four decades (Paasonen 2007). Sharing a moment between men through pornography may allow the pleasures of conventional heterosexual imagery while escaping feminists' judgment. My presence, felt as masculine, allowed the reenactment of those pleasures in the interview time-space. Some interviewees seemed impressed (by my academic status) or shy (in expressing sexual thoughts and sensations), other interviewees took control of the interaction ${ }^{11}$ by giving me the role of the (hetero)sexually inexperienced young man while they staged sexual experience and retold conquests. Participants regaling me with heroic narratives of heterosexual conquest tended to be the most reluctant to refocus the conversation on autosexual practices, despite my repeated invitations. I felt uncomfortable in these situations, both as interviewer losing control of the interaction, and as a queer man. According to Raewyn Connell's theory of masculinities (Connell 2005; Connell and Messerschmidt 2005) my position can be described as both subordinate (less manly), yet complicit: "man enough" to be conscripted into heteronormative male bonding.

The dominant posture towards feminism among gay interviewees is its apparent promotion (through the commonalities of women's and gay men's liberation) combined with rejection when it comes to feminist critiques of representations of masculinity ${ }^{12}$. Laurent (42, gay, manager) framed feminism as the killjoy of his masculine pornographic pleasure:

- A feminist critique of straight porn says that it's a genre made by and for men, to the detriment of women. What do you think?

- Well that's what I like about it! Not so much that it's to the detriment of women. Rather that there's this very masculine vision of sexuality. That's what I'm looking for! That's what turns me on! And, I mean, do women really have to criticize this kind of stuff? [...] This he-she dominant-dominated vision suits me very well because it's what turns me on.

- I can understand your point of view, but what do you think of the feminist view?

- Well I think representations of sexuality should not be limited to this one. It's a very caricatured vision of human relationships. It's one of the visions. It's the dominant one. Men are masculine and like to dominate.

Gay male complicity may also hierarchize masculinities and marginalize feminine and feminist standpoints. Hegemonic complicity here follows a homonormative dynamic, by

\footnotetext{
${ }^{11}$ See also (Pini 2005) for the analysis of such gender display on part of interviewed heterosexual men.

${ }^{12}$ Richard Dyer (1985) suggests most of the gay men around him in the 1980s were reacting to antiporn feminism through antifeminism and male-centered definitions of sexual liberation.
} 
which men and women are considered as two naturally different categories, non-effeminate masculinities are valorized and men of color are exoticized.

\section{From empathy to contradiction}

The final common theme deals with feminist and antiracist critiques of pornography. At the end of interviews I switched from empathic mode, to more critical questioning, employing feminist, queer and antiracist perspectives. Although based on prewritten questions, the level of my critique depended upon interview contexts - my tone might be bold when I felt in control of the interaction, while remaining more appeasing if I felt less so.

Following "the general principle that the unasserted (what is taken as obvious/natural/common-sensical) precedes and dominates the asserted (particular ideological positions advanced within this taken-for-granted framework)" (Morley and Brunsdon 1999: 278), this critical shift sought to force interviewees into exposing their normative views. I asked Julien (28, heterosexual man, manager) about the unidirectional gender power-play in the straight porn he enjoys, he answered: "That's nature [...] Naturally, men are a bit dominant and women are receptive [...] Women usually act nice and pretty and it's the guy who..." Rather than finishing his sentence, Julien mimicked the sexual "top" role: moving his arms and pelvis in a conventionally masculine way. Asked what he meant by "nature", he clarified: "I don't mean homosexuality isn't natural. I just mean there's a fundamental nature." To my observation that his argument serves the interests of heterosexual men, he added that this "fundamental nature" only operates in the domain of sexuality and not in other areas of social life. I suggested the "natural" sexual center of the male body is the prostate, accessed through the anus. Visibly troubled ${ }^{13}$ by my question, he hesitated, and answered "the penis is easy of access" whereas "the anus is difficult to access". Confronted by the queer margins, normative definitions and embodiments of masculinity are exposed.

Switching from empathy to contradiction also makes visible porn viewers' reflexivity: how they make sense of their experiences in relation to public debates on pornography (especially regarding performers' working conditions and the representation of women), and their

\footnotetext{
${ }^{13}$ This moment of queer embarrassment is quickly reframed as a minor disagreement within a courteous rational conversation between two well-educated men.
} 
complex, multifaceted and sometimes contradictory relationships with pornography. In sharp contrast to anti-pornography feminist views, my research reveals that among heterosexual male viewers, those who participate in porn fan cultures (for example debating on forums or editing blogs) are very aware of and interested in feminist critiques. They also express more intense reflexivity towards the gender norms and hierarchies that organize masculinities than other heterosexual men.

\section{Conclusion}

“Troubling complicity" refers to an ambivalent epistemo-political position. As a verb, it refers to the strategic use of my body to uncover the gender dynamics at work in men's uses of pornography: engaging in masculine complicity enabled access to other male viewers' pornographic tastes, fantasies and attractions; switching from empathy to contradiction at the interview's end also exposed participants' normative views and revealed their complex relation to feminist and public debates about pornography. As an adjective, "troubling complicity" refers to an aporia: I rely on hegemonic male bonding in order to contribute to feminist knowledge. Accounting for such ambivalence will hopefully contribute in sophisticating academic and political discussions linking pornographies and masculinities, moving beyond simplistic antiporn and antifeminist statements.

\section{References cited}

Ahmed, Sara. 2004. The Cultural Politics of Emotion, Edinburgh, Edinburgh University Press.

Ahmed, Sara. 2010. 'Feminist Killjoys (And Other Willful Subjects)'. The Scholar and Feminist Online, vol. 8, no. 3.

Attwood, Feona. 2002. 'Reading Porn: The Paradigm Shift in Pornography Research', Sexualities, vol. 5, no. 1, p. 91-105.

Attwood, Feona. 2005. 'What do people do with porn? Qualitative research into consumption, use and experience of pornography and other sexually explicit media'. Sexuality and Culture, vol. 9, no. 2, 2005, p. 65-86.

Attwood, Feona. 2007. "Other" or "One of us"? The porn user in public and academic discourse'. Participations : Journal of Audience and Reception Studies 4 (1).

Bozon, Michel. 2012. 'Sexual Encounters and Sexual Practices: A Widening Repertoire.' In Sexuality in France. Practices, Gender \& Health, edited by Nathalie Bajos and Michel Bozon, 243-264. Oxford: The Bardwell Press.

Burke, Nathaniel. 2014. 'Positionality and pornography', Porn Studies, vol. 1, no. 1-2, 2014, p. 71-74. 
Connell, R. W. 2005. Masculinities. 2nd edn. Berkeley: University of California Press.

Connell, R. W., and James W. Messerschmidt. 2005. 'Hegemonic Masculinity : Rethinking the Concept'. Gender \& Society, vol. 19, no. 6, p. 829-59.

Dyer, Richard. 1985. 'Male Gay Porn: Coming To Terms'. Jump Cut: A Review of Contemporary Media, no. 30, p. 27-29.

Elias, Norbert. 2000. The Civilizing Process. Sociogenetic and Psychogenetic Investigations. Oxford: Blackwell.

Foucault, Michel. 1978. The History of Sexuality. Volume I: The Will to Knowledge. New York: Penguin.

Gagnon, John and William Simon. 2004. Sexual Conduct. The Social Sources of Human Sexuality. 2nd edn. New Brunswick and London: Aldine Publishers.

Goffman, Erving. 1959. The Presentation of Self in Everyday Life. New York: Anchor Books.

Hardy, Simon. 1998. Softcore Pornography and Heterosexual Men. The reader, the autor, his woman and her lover. London: Cassell, 1998.

Irvine, Janice M. 2014. 'Is sexuality research "dirty work"? Institutionalized stigma in the production of sexual knowledge', Sexualities, vol. 17, no. 5-6, 2014, p. 632-656.

Kendrick, Walter M. 1987. The secret museum : pornography in modern culture. New York: Viking.

Kipnis, Laura. 1998. Bound and Gagged: Pornography and the Politics of Fantasy in America. Durham: Duke University Press.

Kulick, Don, and Margaret Wilson (eds). 1995. Taboo. Sex, Identity, and Erotic Subjectivity in Anthropological Fieldwork, London and New York: Routledge.

Lewin, Ellen and William L. Leap (eds). 1996. Out in the Field: Reflections of Lesbian and Gay Anthropologists, Champagne: University of Illinois Press.

Marks, Laura Helen. 2014. 'How did you get into this? Notes from a female porn scholar', Colaboração Internacional, vol. 2, no. 2, p. 120-130.

McKee, Alan, Kath Albury, and Catharine Lumby. 2008. The Porn Report. Mebourne: Melbourne University Publishing.

Morley, David, and Charlotte Brunsdon. 1999. The Nationwide Television Studies. London and New York: Routledge.

Mowlabocus, Sharif, James Harbottle, and Charlie Witzel. 2013. 'Porn Laid Bare: Gay Men, Pornography and Bareback Sex', Sexualities, vol. 16, no. 5-6, p. 523-47.

Paasonen, Susanna. 2007. 'Strange bedfellows: Pornography, affect and feminist reading', Feminist Theory, vol. 8, no. 1, p. 43-57.

Paasonen, Susanna. 2011. Carnal Resonance. Affect and Online Pornography, Cambridge: MIT Press.

Pini, Barbara. 2005. 'Interviewing men Gender and the collection and interpretation of qualitative data', Journal of Sociology, vol. 41, no. 2, p. 201-216.

Probyn, Elspeth. 1989. 'Take my word for it. Ethnography and autobiography'. Journal of Communication Inquiry, no. 13, p. 18-22. 
Probyn, Elspeth. 1993. Sexing the self: gendered positions in cultural studies. New York and London: Routledge.

Radway, Janice. 1991. Reading the Romance. Women, Patriarchy and Popular Literature. 2nd edn., Chapel Hill, NC: University of North Carolina Press.

Schütz, Alfred. 1945. 'On multiple realities.' Philosophy and Phenomenological Research 14 (4): 533-576.

Sedgwick, Eve Kosofsky. 1985. Between men: English literature and male homosocial desire, New York: Columbia University Press.

Shelton, Emily. 2013. 'A Star Is Porn: Corpulence, Comedy, and the Homosocial Cult of Adult Film Star Ron Jeremy'. Camera Obscura, vol. 17, no. 3, p. 115-46.

Skeggs, Beverley, and Helen Wood. 2012. Reacting to Reality Television. Performance, Audience and Value, London and New York: Routledge.

Smith, Clarissa. 2007. One for the Girls! The Pleasures and Practices of Reading Women's Porn. Bristol : Intellect.

Smith, Clarissa, Martin Barker, and Feona Attwood. 2015. 'Figuring the Porn Audience.' In New Views on Pornography: Sexuality, Politics, and the Law, edited by Lynn Comella and Shira Tarrant. New York: Praeger, p. 277-296.

Smith, Clarissa, Martin Barker, and Feona Attwood. forthcoming. « Teenage Kicks: Young People's Engagements with Pornography, Some Results from Pornresearch.org Questionnaire ».

Waugh, Thomas. 2004. 'Homosociality in the Classical Stag Film : Off-Screen, On-screen'. In Porn Studies, édité par Linda Williams, 127-41. Durham and London: Duke University Press.

Williams, Linda. 1991. 'Film Bodies: Gender, Genre, and Excess'. Film Quarterly 44 (4): $2-13$. 